\title{
Por um diálogo plural e fecundo
}

Professor do Defhe (Unicamp) e Coordenador Executivo do Paideia

brir uma edição inaugural de uma Revista eletrônica é,
para todo professor, uma tarefa por demais honrosa. Pois
significa socializar para dimensões inusitadas a produção criteriosa e fecunda de um determinado lugar, grupo ou conjunto de pesquisadores, colegas de ofício e companheiros e companheiras de ensino, pesquisa, atuação institucional e política no campo em questão. No presente caso, tenho a alegria e a honra de anunciar o número especial da Revista Digital PAIDEIA, concebida para tornar pública a dinâmica institucional e a fecunda produção do Grupo de Estudos e Pesquisas em Filosofia e Educação PAIDEIA, um dos destacados grupos de pesquisa do Programa de Pós-Graduação da Faculdade de Educação da Universidade Estadual de Campinas (UNICAMP).

O Grupo PAIDEIA, tal como é denominado e conhecido usualmente este grupo de investigadores, completou 10 anos de existência institucional em 12 de maio de 2009. Embora tivesse já um perfil próprio, pela produção original e relevante dos pioneiros professores e pesquisadores da área da Filosofia e Educação, foi notadamente após a remodelação geral da pesquisa e pós-graduação da FE, ocorrida nos anos 1990, que o PAIDEIA tomou a configuração institucional atual, precisamente a partir do final da década aventada. 
A trajetória e a produção acadêmica nesses 10 anos de consolidação histórica do PAIDEIA se destaca pela pluralidade temática, pela singular originalidade, pela determinada relevância social e ampla qualidade reflexiva, pedagógica e política, de sua intervenção institucional. Artigos, livros, capítulos de livros, resenhas, boletins bibliográficos, resumos e produtos didáticos, de diferentes linhas de pesquisa, somam-se às teses doutorais, estudos e pesquisas de pósdoutoramento, dissertações de mestrado e basilares monografias de conclusão de cursos ou iniciação científica, no campo temático da Filosofia da Educação.

Outro destaque e igualmente um registro memorável necessariamente relembrará os Colóquios mensais, há anos alimentados e mantidos pelo Grupo, em consonância com outros universos organizacionais do Departamento de Filosofia e História da Educação (DEFHE/FE). E acrescenta-se a esse espectro a rica e já consolidada tradição de produção, promoção e gestão de eventos científicos, de convocação de reuniões de pesquisadores a propiciar trocas de conhecimentos, produções científicas e debates como foram os ocorridos no I, II e III EPISTED, mantidos pela linha Epistemologia e Teorias da Educação, o I e o II Simphilo, um já organizado e realizado e o segundo agora em planejamento, para dezembro de 2009, coordenado pela linha de pesquisa denominada Ensino de Filosofia; bem como relembramos a rica produção do I Poiethos, efetivado pela linha investigativa Política, Ética e Educação. 
Por essa digressão descritiva e histórica se pode concluir que a Revista Filosofia e Educação é o coroamento legitimador e plenificante da vida institucional, da rica produção e da original intervenção do Grupo PAIDEIA em sua área de pesquisa e na sociedade científica e política atual. Esperamos que esse número especial seja o penhor da trajetória histórica dos 10 anos do PAIDEIA e o fiador estimulativo e projetual dos anos, da produção e da dinâmica dos eventos que virão, para a Filosofia e a Educação. Que a Revista Digital do PAIDEIA condense a pluralidade temática, a dialogicidade política, a fecundidade analítica e interpretativa e retrate, ao mesmo tempo, a solidez do rigor conceitual, da determinação ética, da natureza estética e política própria do pensamento filosófico e sua singular abordagem do fenômeno social da Educação. 